\title{
Common Clinical Manifestations of Human Papilloma Virus (HPV) Infection
}

\author{
A. Guerra-Tapia ${ }^{*}, 1$, E. González-Guerra ${ }^{2}$ and C. Rodríguez-Cerdeira ${ }^{3}$ \\ ${ }^{I}$ Dermatology Department, Hospital Doce de Octubre, Madrid, Spain \\ ${ }^{2}$ Infanta Cristina Hospital, Madrid, Spain \\ ${ }^{3}$ Dermatology Department, CHUVI \& University of Vigo, Vigo, Spain
}

\begin{abstract}
The Papillomaviruses are DNA viruses which belong to the Papova family, having a great affinity for epithelial tissue. They can produce proliferative lesions either in the skin or mucosa, either in man or other animals. Various kinds of lesions, mainly benign, are caused by numerous types of human papillomavirus (HPV) involving the well-known verruca vulgaris, respiratory laryngeal papillomatosis, condylomata acuminata and focal epithelial hyperplasia, as well as a possible association with other alterations and lesions.
\end{abstract}

We present in this paper an update on common clinical manifestations and treatment of HPV infection.

Keywords: Verruca vulgaris, respiratory laryngeal papillomatosis, condiloma acuminatum, treatment.

\section{INTRODUCTION}

The most common clinical manifestation is the verruca, with its different morphological forms: verruca vulgaris, verruca plana, anogenital warts or condylomata acuminata (CA), and Levandowsky-Lutz. Frequently the HPV 1, 2, 3, 4, 5 and 8 subtypes are detected.

The histological study results are similar in all of them; they show alcanthosis, elongation of the dermal papillae, presence of vacuolated cells with dense and wrinkled nuclei and with basophilic inclusion, composed of viral particles, and eosinophilic inclusions of abnormal keratin in the superficial layers of the epidermis (coilocytes).

\section{VERRUCA VULGARIS}

Verruca vulgaris are the most common warts and are produced by serotypes 2 and 4 . They are papules with rough surfaces, firm consistency, colour similar to the surrounding skin, brown or greyish, but always uniform, and generally less than $1 \mathrm{~cm}$ in diameter. They may form large masses by coalescence. They are asymptomatic. Although they may be found in any part of the skin, they are preferably found on the fingers and back of the hand and, in children, on the knees. The periungeal form is generally painful and, frequently, produces dystrophy, which is seen as deformity of the nail. On the face, neck and periorificial areas they generally have an elongated shape with a small fixation base (filiform warts) (Figs. 1-3) [1].

\section{VERRUCA PLANA}

These are associated with types 3 and $10 \mathrm{HPV}$. They are small papules which are hardly raised, flat, skin coloured,

*Address correspondence to this author at the Dermatology Department, Hospital Doce de Octubre, Madrid, Spain;

Tel: 606626124; Fax: 914608377;

E-mails: auroraguerratapia@gmail.com, aurora@auroraguerra.com

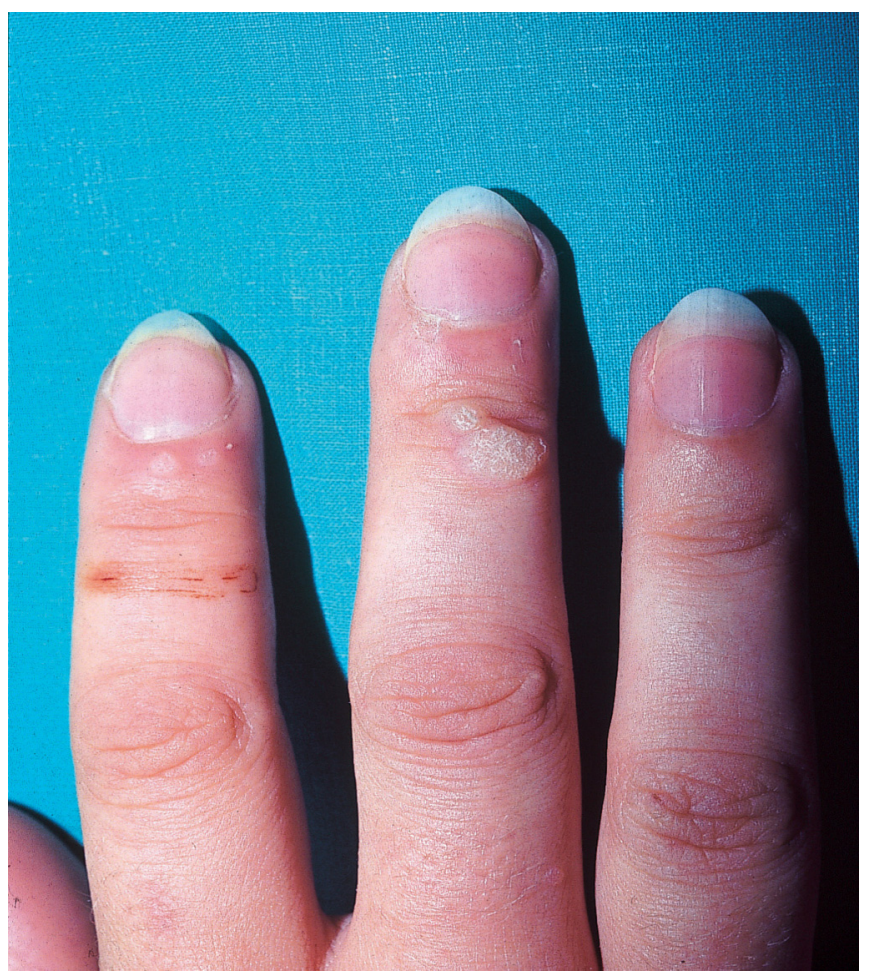

Fig. (1). Periungeal warts.

grey or yellowish, rounded or polygonal, and are less than 5 $\mathrm{mm}$ in diameter. They are found in the peripheral areas of the face, back of the hands and pretibial areas in children and youths. Lineal grouping is typical following scratch lines (isomorphism) (Fig. 4) [1].

\section{PLANTAR WARTS}

These are associated with types 1,2 and 4 HPV. They are observed in two forms: endophytic and exophytic or in a mosaic. Endophytic plantar warts are generally unique, deep, 
painful and are manifested by a circumscript keratinous plaque, with a black pointed central area (thrombosed capillaries) and with the periphery of the whole lesion covered by a thick whitish keratinous ring. They are found in weight bearing areas of the foot, particularly on the front plantar arch (Fig. 5).

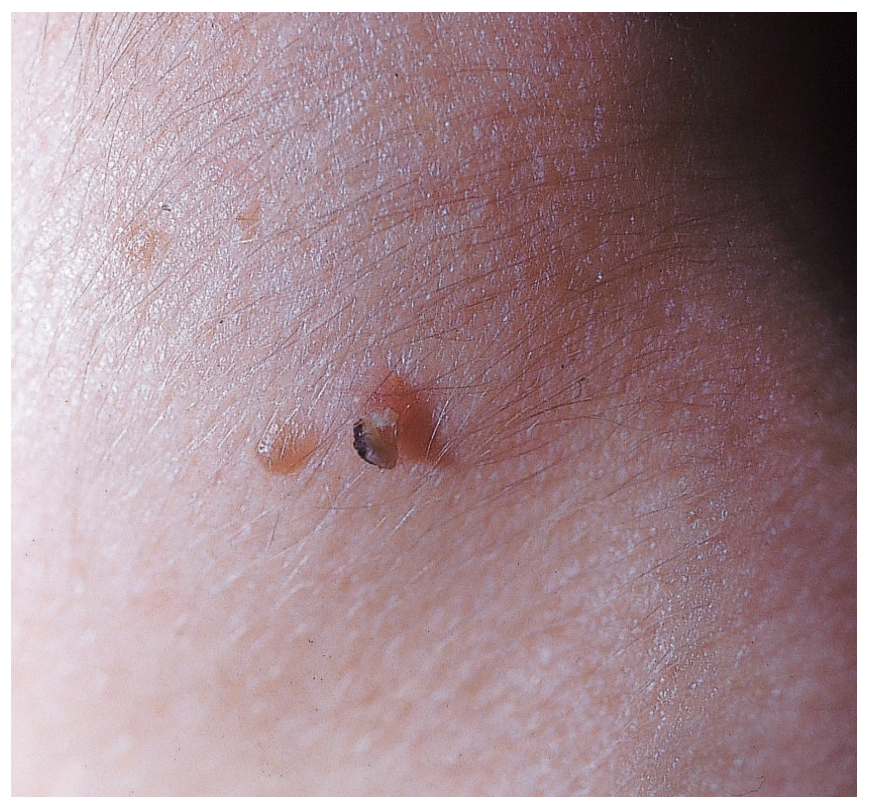

Fig. (2). Filiform warts in the neck.

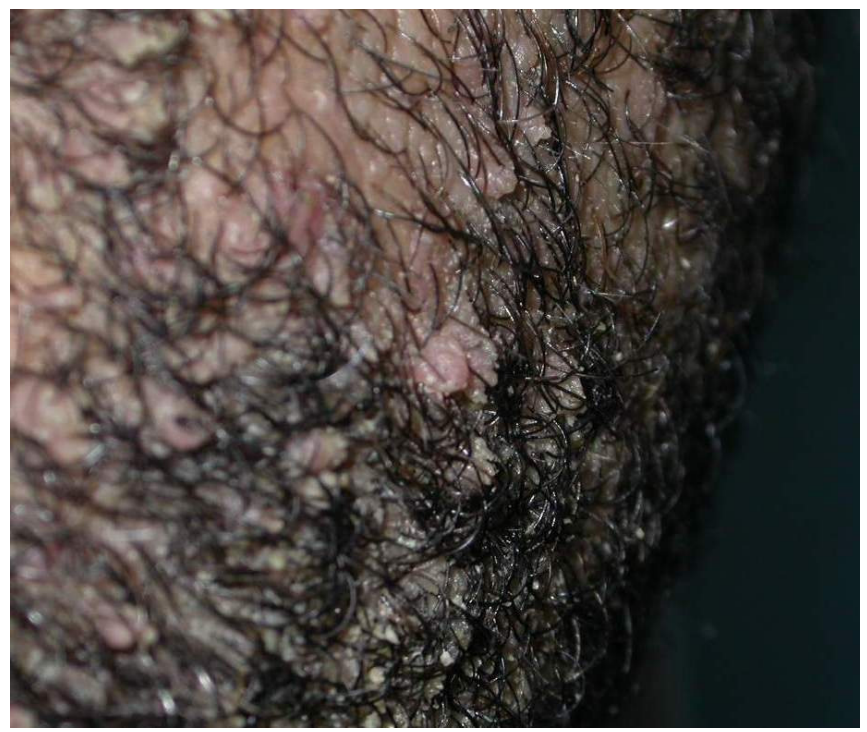

Fig. (3). Warts in the beard.

The exophytic plantar verruca or mosaic plantar verruca are generally multiple, superficial, painless or only slightly painful, and are manifested by a slightly raised plaque formed from circumscript keratinous lesions grouped together into a mosaic. They are most frequently found on the heels.

At present no specific antiviral treatment exists for HPV infection, so the various treatments available try to destroy all the cells infected by the virus or attempt to get the individuals own immune system to destroy them.
Therefore, the objective of the treatment is to eliminate the cutaneous lesions with minimum damage to the normal tissues. The treatment will depend on the type of warts, their number, size and location, the experience of the doctor and the wishes of the patient. A conservative treatment is always recommended due to the tendency for warts to spontaneously remit. If the warts do not disappear on their own accord they may be treated with irritant liquids to stimulate the body's defences against virus and keratolytics to reduce their size. In the case that these fail to be effective, methods such as cryotherapy, electric scalpel or laser may be used (Tables 1 and 2) (Fig. 4) [1, 2].

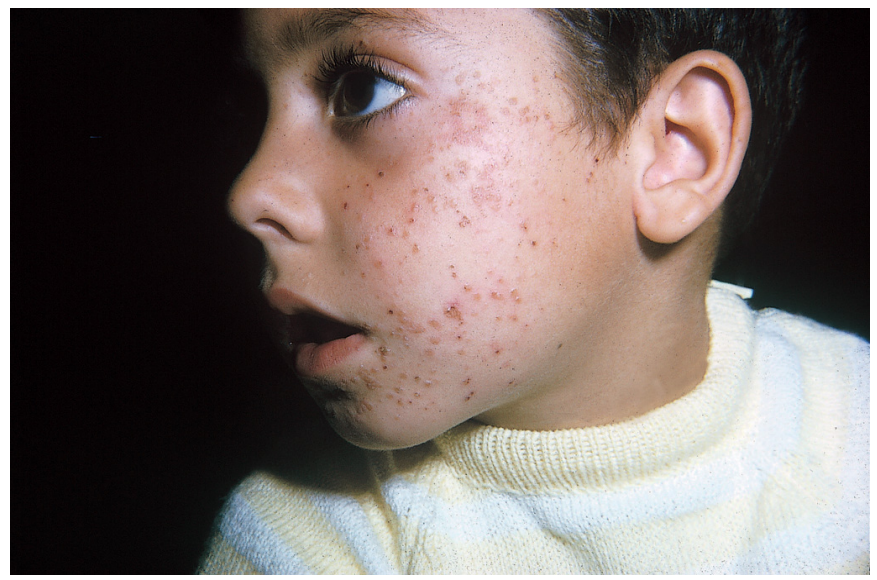

Fig. (4). Verruca plana on the face of a child.

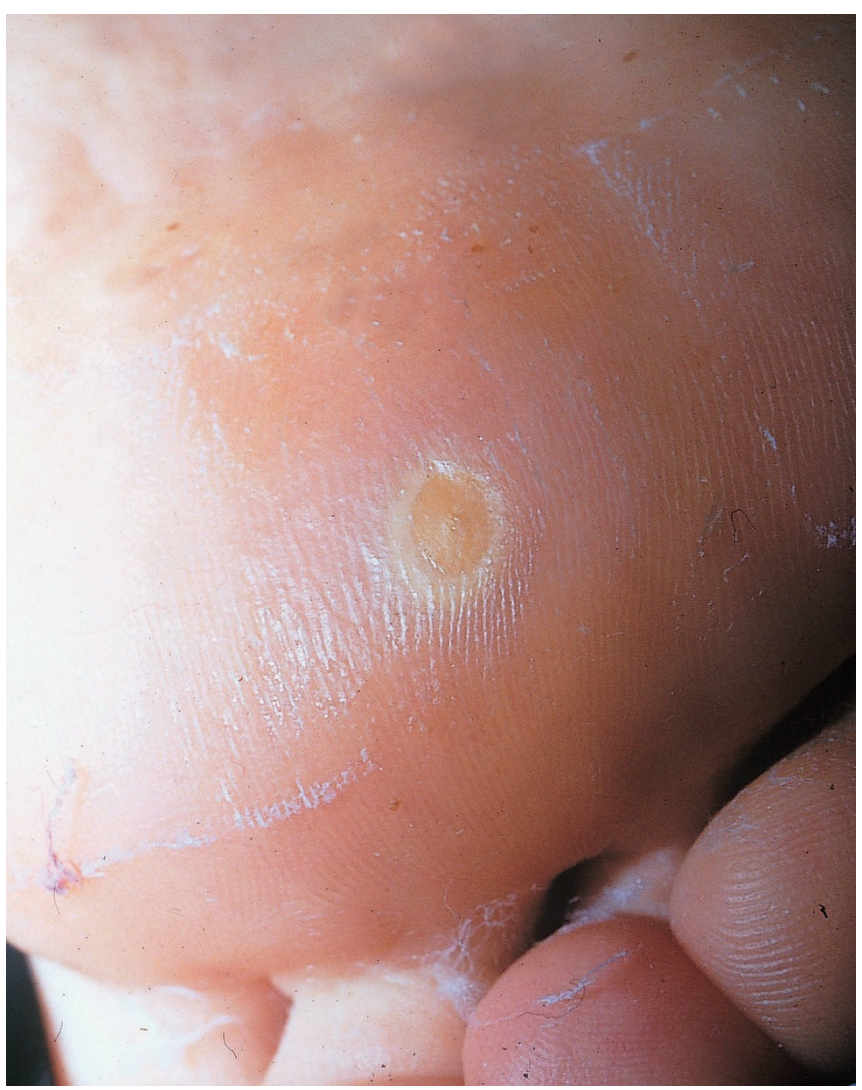

Fig. (5). Plantar warts.

In immunodepressed patients good results have been achieved with the antigen of the Candida genus [4]. 
Table 1. Different Types of Treatments

\begin{tabular}{|c|c|}
\hline Surgical Treatment & $\begin{array}{l}\text { Electrodessication and/or curettage } \\
\text { Excision } \\
\text { Laser (extremely effective) }\end{array}$ \\
\hline Cryotherapy & With ethyl chloride or liquid nitrogen. \\
\hline Radiotherapy & $\begin{array}{l}\text { At present not used due to high rate of undesirable } \\
\text { effects. }\end{array}$ \\
\hline Photochemotherapy & $\begin{array}{l}0.15 \% \text { solution of } 8 \text {-methoxypsoralen, followed by } \\
\text { sessions of UVA. }\end{array}$ \\
\hline Keratolytics & $\begin{array}{l}\text { The most used is salicylic acid. The healthy skin } \\
\text { should be protected. }\end{array}$ \\
\hline Tretinoin & The treatment choice for verruca plana. \\
\hline Interferon & $\begin{array}{l}\text { Interferon } \alpha 2 \mathrm{a}, \alpha 2 \mathrm{~b}, \beta \text {, above all in very widespread } \\
\text { and resistant cases. }\end{array}$ \\
\hline Psychotherapy & Has its main application in young children. \\
\hline Others & $\begin{array}{l}\text { Formaldehyde, bleomycin, 5-flourouracil, } \\
\text { cantharidin, podophyillin, } 20 \% \text { ammoniated } \\
\text { mercury, glutaraldehyde, immunotherapy, zinc } \\
\text { sulphate and cimetidine*. }\end{array}$ \\
\hline
\end{tabular}

\section{EPIDERMODYSPLASIA VERRUCIFORM (LEVAND- OWSKY-LUTZ)}

This is a rare hereditary disease, transmitted with autosomal recessive character, which determines an abnormal immunological response to HPV infection. Family consanguinity is often observed. It is more frequent in women. There is mental retardation observed in $10 \%$ of the cases.

The clinical picture begins in infancy and is characterised by the presence of lesions which appear similar to verruca vulgaris and verruca plana, which tend to be located in areas exposed to the sun: back of the hands, forearms, sides of the neck and face. Hypochromic maculose lesions are also observed on the trunk. In a third of the cases, starting from the second or third decade of life, there is a malign transformation of the lesions, above all in areas exposed to the sun, which are mainly related to HPV 5 and 8 , but also with 3 , and to a lesser extent, with $9,12,14,15,17,19-25$, $36-38,46,47,49,50$ etcetera [1].

\section{BUTCHER'S WARTS}

They owe their name as they are observed in professionals who process meats. They are extensive verrucous papules or in the shape of a cauliflower on the back, palm or periungeal borders of the hands and fingers and are associated to HPV 7 [1].

\section{CONDYLOMATA ACUMINATA}

CA also known as genital warts, venereal papillomas or venereal warts are characterised by the presence of fleshy excretions found generally in the mucous membranes of the anogenital area. CA will appear in the area of the mucous membrane or skin where an infection has been found.

CA are generally of exophytic appearance, are generally pediculed and papular, with a sessile base, and even occasionally flattened. In the mucous membranes the CA are observed with the aspect of a hyperplastic lesion, fleshy and humid, with a pink or white colour, due to the maceration that is generally associated with them, by the neighbouring secretions or a secondary concomitant infection. These clinical signs vary when the condylomas are found in surrounding skin, with an aspect of dry and hyperkeratinous lesions being possible or even as pigmented papules. During their development, CA can remain indefinitely with the aforementioned characteristics, evolve or progressively extend. In the latter case they may form wide infiltrated plaques of a tumoural and mamelonated aspect, which may even mask the anatomical signs of the area where they are found (giant condylomas).

The second clinical aspect of $\mathrm{CA}$ is their appearance as small, multiple papules which vary between 1 and $6 \mathrm{~mm}$ in

Table 2. Most Frequent Treatments Used Daily in the Consultancy

\begin{tabular}{|l|l|l|l|l|}
\hline & \multicolumn{1}{|c|}{ Hands } & \multicolumn{1}{|c|}{ Feet } & \multicolumn{1}{|c|}{ Face } & \multicolumn{1}{|c|}{ Rest of Body } \\
\hline \hline Verruca vulgaris & $\begin{array}{l}\text { Local application of } \\
\text { salicylic acid or lactic acid, } \\
\text { glutaraldehyde, } \\
\text { cryotherapy, curettage and } \\
\text { electrodessication } \\
\text { Imiquimod }\end{array}$ & $\begin{array}{l}\text { Local application of } \\
\text { salicylic acid on a dressing } \\
\text { with 40\% glutaraldehyde, } \\
\text { cryotherapy, curettage and } \\
\text { electrodessication, } \\
\text { Imiquimod }\end{array}$ & $\begin{array}{l}\text { Local application of salicylic acid, } \\
\text { cryotherapy, Imiquimod curettage } \\
\text { and electrodessication }\end{array}$ & $\begin{array}{l}\text { Cryotherapy, curettage and } \\
\text { electrodessication } \\
\text { Imiquimod }\end{array}$ \\
\hline Filiform warts & Cryotherapy, electrodessication and /or curettage & \\
\hline Verruca plana & $\begin{array}{l}\text { Tretinoin } \\
\text { Local application of salicylic acid } \\
\text { Cryotherapy and electrodessication } \\
\text { Imiquimod } \\
\text { Tretinoin }\end{array}$ & $\begin{array}{l}\text { Glutaraldehyde, cryotherapy, electrodessication, laser } \\
\text { Imiquimod }\end{array}$ \\
\hline Plantar warts &
\end{tabular}


diameter. They are generally indurated to the touch and are generally found on the edges of the mucous membrane with the skin (papular condylomas) $[1,5]$.

\section{a) Localization of Condylomata Acuminata in Men}

In the genitals of men the most frequent affected areas are the frenulum, balanopreputial fold and the mucous membrane of the penis and foreskin, presumably as these are areas which are exposed to the greatest trauma during coitus. The urethra may also be affected, but in the anterior part, generally in its first segment, and rarely in more distant segments. CA may also be found in the scrotum and perigenital areas, albeit in generally sub-clinical forms. The location of $\mathrm{CA}$ in the anal region is generally related to anal coitus in $90 \%$ of the cases. In $50 \%$ of the cases it may affect the rectal mucous membrane. It is necessary to examine the area using anuscopy. The clinical aspect is generally papillomatose (Figs. 6-8) [6].

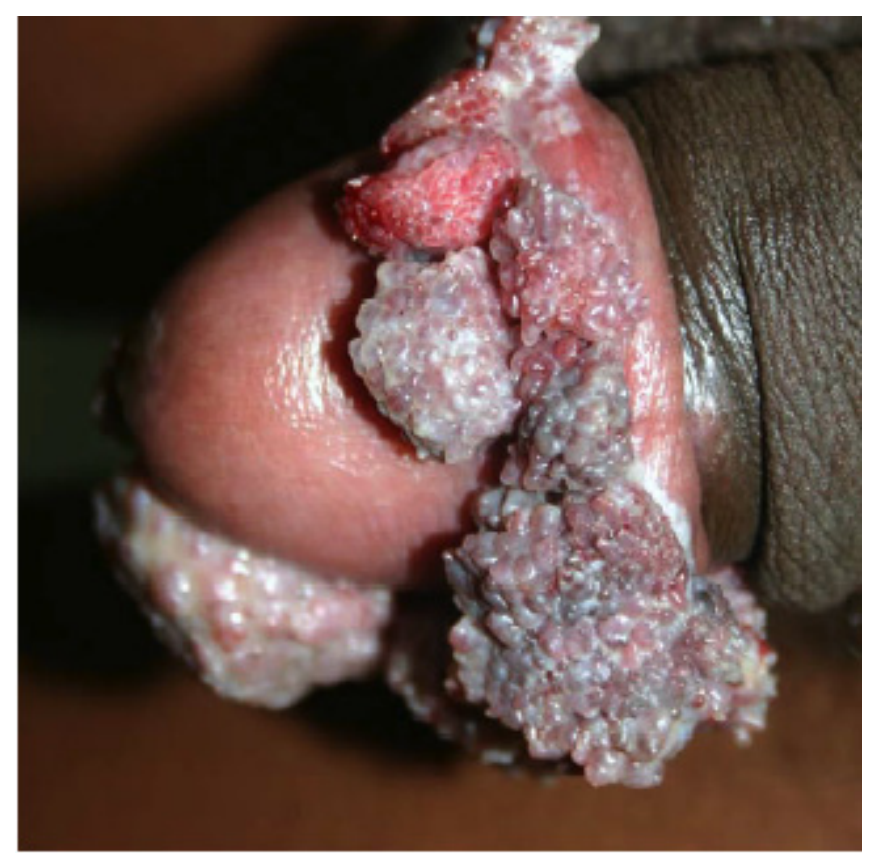

Fig. (6). Condylomas acuminatas on the gland and preputial-balanic fold in a HIV+ patient.

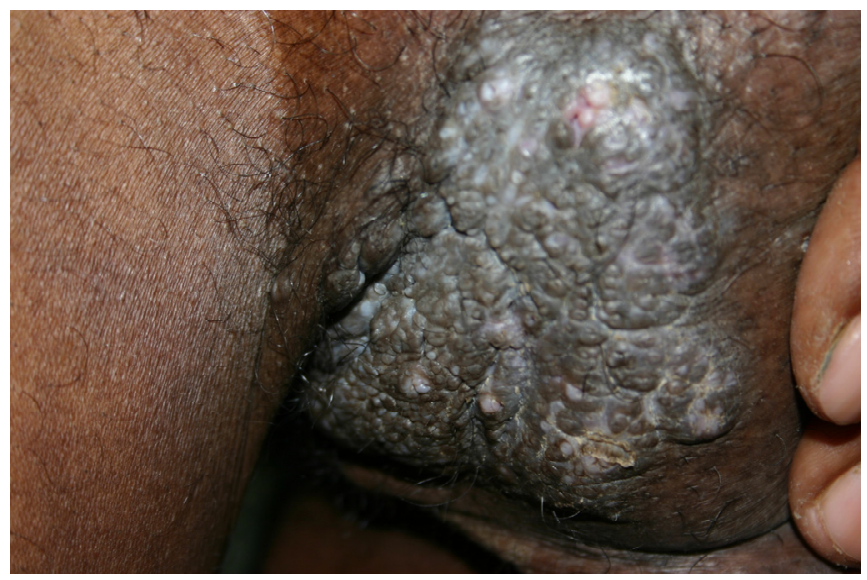

Fig. (7). Scrotal condylomas.

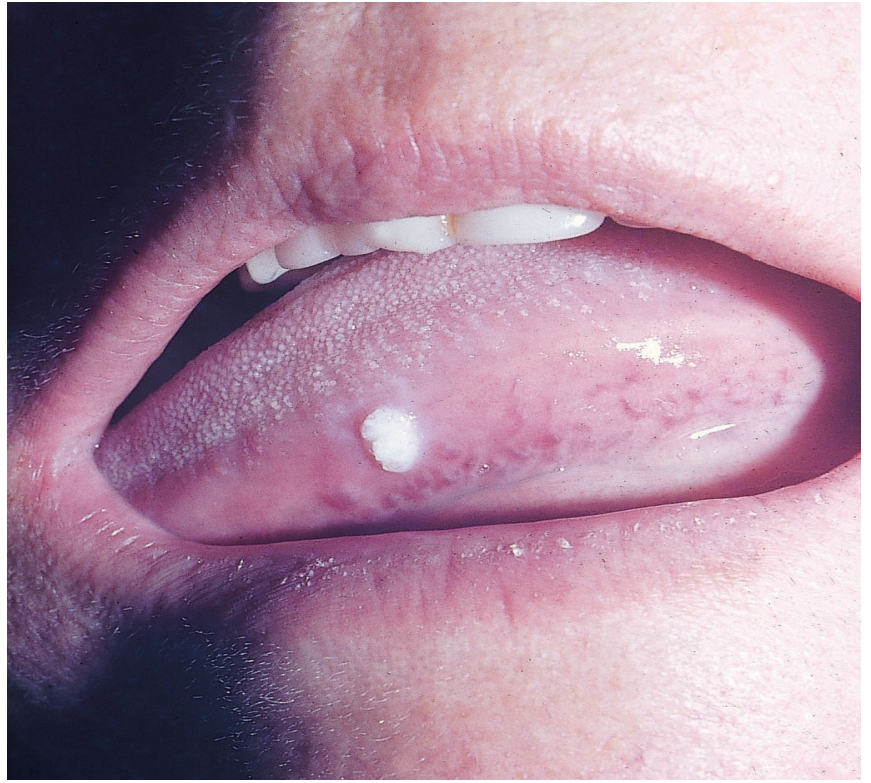

Fig. (8). Condyloma acuminata on the tongue.

\section{b) Location of Condylomata Acuminata in Women}

Exophytic CA appears in women, generally, first found in the fouchette and greater and lesser lips of the pudendum, but due to the humid conditions of the female genital apparatus and possible associated infections it generally rapidly propagates to all the vulva, and even the perineum and perianal area.

In the vulva and perineum they can be observed as exophytic condylomas or as lesions of the papular, micropapillar or macular types. Colposcopic exploration of this area would be totally necessary and more accentuated in the introitus and interlabial folds.

CA located in the anus, both in men and women are generally exophytic and may be related with anal coitus, but also with the possible propagation of vulvar secretions. It is totally necessary to perform both genital and anal examinations together (Fig. 9) [5].

\section{Sub-Clinical Manifestations}

These are extremely important, above all epidemiologically, as they are invisible to the human eye. As a general rule, sub-clinical lesions are flattened and multiple. Their clinical insignificance facilitates their spread, and their persistence is possibly related to genital cancer, above all in women. They may be observed by application of a solution of acetic acid followed by viewing using a magnifying glass or colposcope.

\section{Manifestations of Genital Infection by HPV in Women}

Once HPV has infected any region of the epithelium of the inferior genital tract, in approximately $80 \%$ of the cases the organism will totally eliminate the infection, whilst in the rest of the cases the virus may remain latent, even for decades, in which case, it is only possible to diagnose through molecular biological methods, which detect the presence of viral DNA, or rather enter into a stage of active expression with morphological manifestations depending on 
the induced histology in the epithelium, which present as clinical or sub-clinical manifestations.

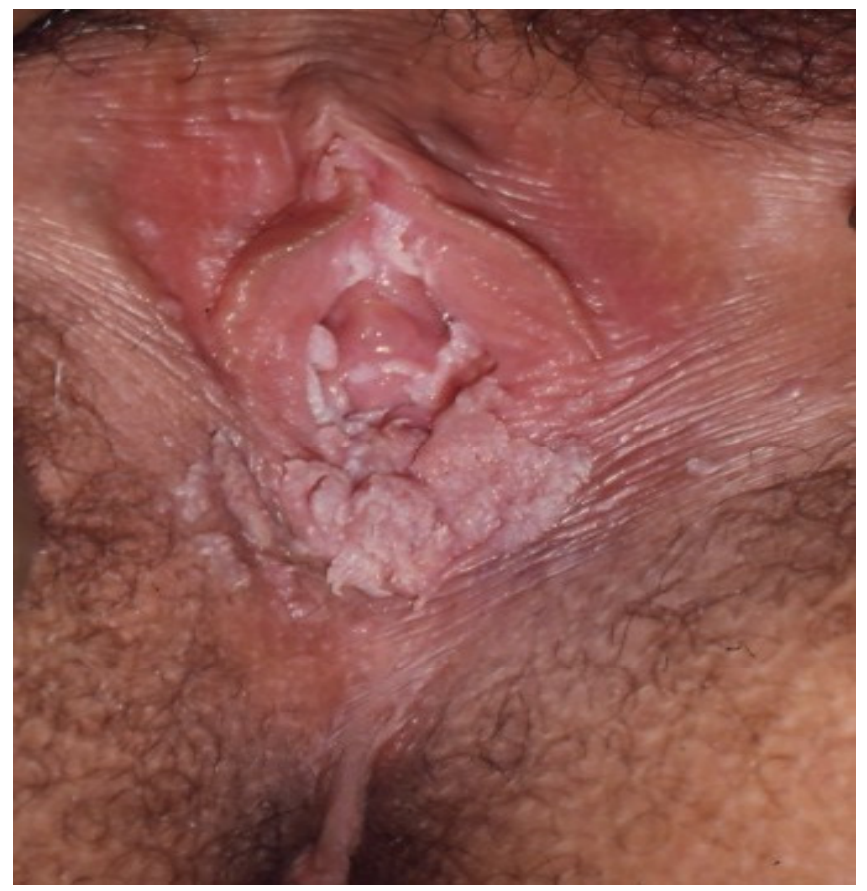

Fig. (9). Condylomatous masses in the fouchette and perineum.

The clinical forms are generally benign, whilst the subclinical may be expressed as benign lesions or precursory lesions with the potential to develop malignant lesions.

Although the clinical lesions are evident with direct ocular examination, broadened examination via colposcopic allows a more real evaluation of the extension of the disease and better evidence of its clinical aspects, on which a correct therapeutic plan will depend. On the other hand, sub-clinical lesions are only evident on colposcopic examination after applying 5\% acetic acid. These lesions may affect any area of the inferior genital tract and the simultaneous existence of mixed forms of clinical and sub-clinical manifestation is frequent.

Clinical lesions are seen as CA or genital warts, which macroscopically appear to be made of a series of papilla of fleshy appearance, which sprout from a common root, more frequently, extensive and keratinised on the cutaneous surface than on the mucous membranes, with a characteristic cockscomb or cauliflower appearance and with a highly variable size and extension. A very infrequent form is the giant condyloma, in general benign, although it is sometimes seen with malignant histology of the verruciform carcinoma, known as the Buschke-Lowenstein tumour. Rounded, slightly raised, papular forms may also be seen in the vulva, which whiten with acetic acid and are sometimes pigmented (bowenoid papulosis), in which case a possible serious preneoplastic lesion (in situ carcinoma), or macular lesions, reddish or grey-white, which generally affect the mucous membranes should be suspected. Condylomas are nearly always benign, although 5\% may contain oncogenic virus, whilst the papules and macules may have from HPV's without important histological repercussions to serious precursory lesions, and should, thus, always have a biopsy performed on them.
The sub-clinical lesions are found on the majority of the mucous membranes and are seen as white coloured stains, which appear after the application of acetic acid and should be interpreted by a specialist. In the cervix, infection by HPV may affect the squamous epithelium or the joining area between the glandular and squamous epithelium in the same way. Outside these, the acetowhite epitheliums express either a sub-clinical HPV infection or abnormal epithelium with defects in maturity and benign character, whilst within these, apart from the changes referred to, they may indicate HPV-associated preneoplastic lesions with various grades of severity, and as such should undergo biopsy for histological confirmation and be evaluated by a specialist, who, depending on the morphological form, will decide on the most convenient places for taking the biopsy (Fig. 10) [7$10]$.

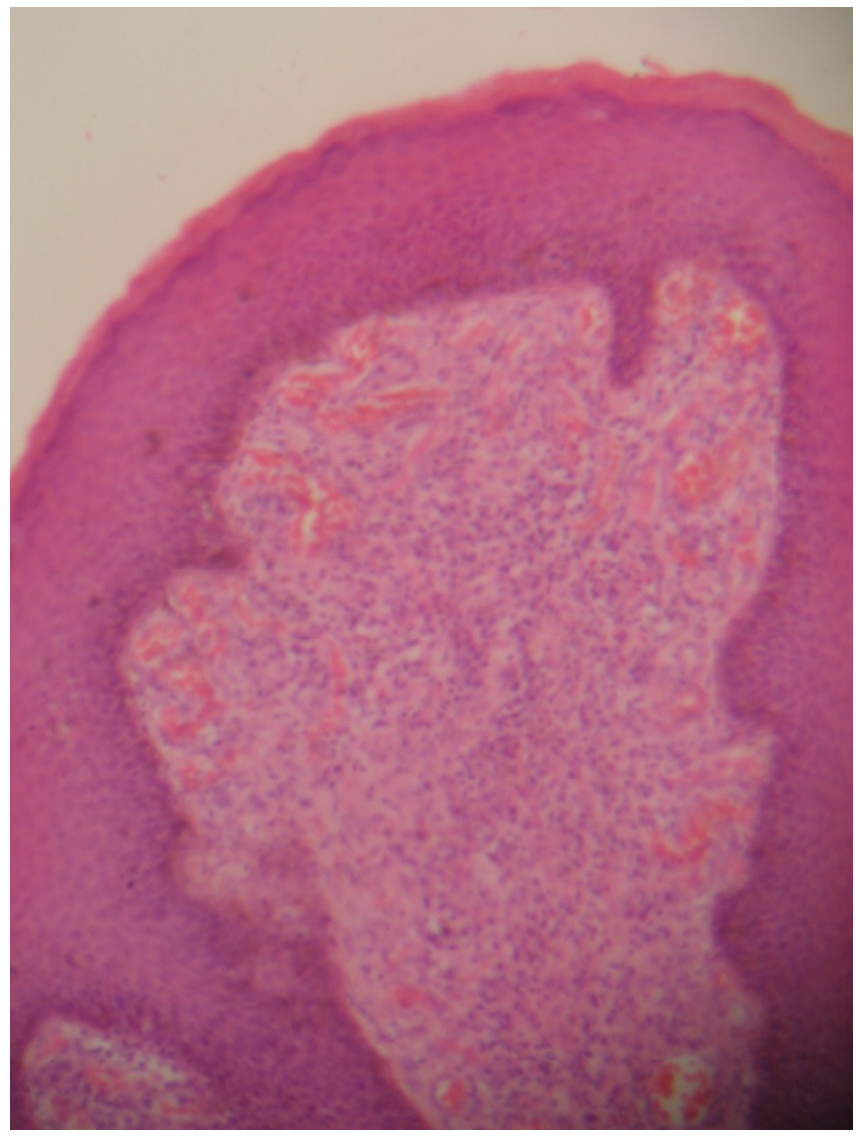

Fig. (10). Vegetative tumourations made up from irregular acanthosis and accentuated papillomatosis.

\section{Treatment and Follow-Up of Condylomata Acuminata}

The treatment of CA should be established in the context of the fact that they are going to have therapeutic failures, and a moderate to high rate of relapses $(8-33 \%)$, so the therapeutic objective will be to achieve periods without condylomas and not apply highly aggressive methods. Nonetheless, the treatments we have available still have secondary effects (stinging, pain, ulceration, etcetera), which the patient must be informed about. Moreover, we do not have a specific treatment for CA and the disappearance of the condylomatous lesion does not imply the elimination of HPV. 
The previous treatment method consisted of ruling out other possible associated sexually transmitted diseases and included exploration of the sexual partner(s) and their treatment. The treatment plan in each case would be determined by a series of factors, which could condition the therapeutic choice, such as:

1. Number, size and anatomical distribution of the lesions. Their extension, grade of keratinisation, time of development and resistance to other treatments.

2. The immunological state of the patient.

3. The effectiveness, availability and ease of application of the therapeutic method.

4. Toxicity.

5. Cost.

6. Age.

7. Preference and previous experience of the patient.

8. Experience of the health professional with respect to the method used.

Although the possibility of spontaneous regression may exist, the generalised tendency is to treat the clinical lesions in order to control the disease, relieve the anxiety of the patient and improve their self-esteem. The possibility that they contain oncogenic virus, albeit infrequently, is yet another reason that leads to treatment.

The chosen methods used at present, following the latest recommendations of the CDC-1998 in the USA, which are also used in Spain, are of two types: methods applied by the patient themselves, such as $0.5 \%$ podophyllotoxin in solution or gel or $5 \%$ imiquimod cream, and methods administered by a specialist consultant, such as cryotherapy with liquid nitrogen, surgical extirpation or $10-25 \%$ podophyllin resin.

\section{Therapeutic Methods Administered by the Patients Themselves}

$0.5 \%$ podophyllotoxin is locally applied twice a day for three consecutive days, followed by four days without treatment, with this regime being repeated for up to four cycles (four weeks). It is effective for condylomas of the penis and vulvar cutaneous lesions. The risk of systemic toxicity is low although it may produced slight local irritation. It is contraindicated for mucous membrane lesions and during pregnancy. $0.15 \%$ podophyllotoxin cream is effective for anal CA. They are, in general, recurrent.

Topical 5-flourouracil is infrequently used and is highly irritant, although it may be of use in mucous membrane lesions, including those associated with intraepithelial lesions, with treatment being done under strict medical control due to the risks of long-term ulcerations.

Imiquimod is the first of a family of molecules (imidazoline heterocyclic amines) which, as opposed to the treatments available to date, does not work by destroying the lesions but rather by inducing the local synthesis of cytokines, mainly interferon alpha, thus modifying the immunological response of the organism infected by HPV. This way of working leads to the elimination of the lesions, as was demonstrated in the double blind placebo controlled study in which 311 patients were included and which reached a rate of complete elimination of the external genital and perianal warts in $56 \%$ of the group treated with $5 \%$ imiquimod cream. The effectiveness observed was higher in women $(77 \%)$ than in men $(40 \%)$, although these percentages considerably increased $(81 \%$ of all patients, $91 \%$ of women and $74 \%$ of men) when the variable measured was elimination equal to or greater than $50 \%$ of the area of the verrucas. The therapeutic effects of Imiquimod were seen in the first 2-4 weeks, with the mean time for complete disappearance of the lesions being 8 weeks in women and 12 weeks in men [11].

One of the most interesting findings in this study was the low remission rate of $13 \%$ at 12 weeks, which could be in relation to the potential immunological response given by imiquimod. The treatment was well tolerated by the patients, with erythema appearing in a third of the patients and erosion or ulceration with lower frequency. Only $6 \%$ of the patients experienced pain. In the majority of cases the reactions were slight or moderate, leading to a rate of abandonment of the therapy below $2 \%$.

\section{Therapeutic Methods Administered by Health Professionals}

The therapeutic methods recommended by the CDC to be administered by health professionals, such as cryotherapy with liquid nitrogen, $10-25 \%$ podofilin resin or surgical extirpation with cold scalpel or electrocoagulation, should be chosen according to the experience of the specialist, and the basic equipment available for application, which are generally found in specialist centres or hospitals.

Other alternative treatments, such as $\mathrm{C}^{2}$ laser or treatments in uncommon places, such as the CA of the urethral meatus or anal $\mathrm{CA}$, which occasionally require general anaesthesia, should always be referred to a hospital, as they sometimes require a multidisciplinary approach.

Of the topical treatments applied by the doctor, $10-25 \%$ podofilin resin is now unused, due to its side effects, toxicity and unpredictable dosage. $\mathrm{Bi}$ - and tricholoroacetic acids are also infrequently used in our environment, being used on mucous membranes, non-extensive lesions and during pregnancy $[1,5]$.

Among surgical treatments we may include surgical excision using scissors or cold scalpel and also electrocoagulation, which, although it is difficult to control the depth of destruction, may be advisable when there are a small number of lesions. Cryotherapy with liquid nitrogen is greatly used at present as it controls the depth of destruction better and is highly effective. The use of $\mathrm{C}^{2}$ laser allows for greater control of the depth of destruction and attains good results.

In general, in the case of initial lesions, which are small and localised, topical therapies are recommended which are applied by either the patients themselves or the doctor, whilst in old, more extensive and relapsed lesions surgical treatment should be used. In very extensive and relapsed lesions the possibility of a mixed treatment of medical and surgical should be considered.

New treatments introduce substances derived from green tea (Polyphenon E) in $15 \%$ cream, which contain 
polyphenols and catechin. The authors obtained variable results [12].

Another innovative technique is using ultrasound technology for anal and perianal CA. The authors obtained good results using this technique [13]. Fluoracil combined with lidocaine is used with excellent results in urethral lesions [14] (Table 3).

Table 3. Special Situations

\begin{tabular}{|c|c|}
\hline Children & $\begin{array}{c}\text { A confirmatory biopsy should be carried out. } \\
\text { Surgical exeresis with local anaesthetic and or laser. } \\
\text { Evaluate the existence of sexual abuse. }\end{array}$ \\
\hline Pregnancy & $\begin{array}{r}\text { Conventional surgery and cryotherapy may be used } \\
\text { even before full-term TCA }{ }^{1}\end{array}$ \\
podophyllotoxin is contraindicated. \\
Imiquimod has not been approved. \\
The majority disappear spontaneously after delivery. \\
$\begin{array}{c}\text { Vaginal delivery should be used except in cases of } \\
\text { obstruction of the delivery canal or important risk of } \\
\text { haemorrhage. }\end{array}$
\end{tabular}

Anogenital CA are awaiting more conclusive results with immunotherapy using Mycobacterium w (Mw vaccine). Initially $0.1 \mathrm{ml}$ is intradermally injected in the deltoids, followed by an intralesional injection at two weeks and is repeated weekly for a maximum of 10 weeks [15]. Photodynamic therapy is successfully being used albeit pending more conclusive results [16].

Another antiviral drug is Cidofovir which is intravenously used in AIDS patients. At present it may be used topically or intralesionally [17] (Table 3).

A group of HIV+ patients satisfactorily evolved with IFN-PEG. They were administered subcutaneously at a dose of 80 micrograms once a week for 24 weeks [18].

\section{Follow-Up of the Patients Treated and their Partner(s)}

Once the CA are treated and eliminated, the patient should be periodically examined, above all in the first three months, which is when most relapses exist. Nonetheless, their control should be longer term, recommending the patient to perform their own examinations, educating and advising them on any doubts with respect to the contagiousness and later relapses and sometimes helping them in physiological matters.

The sexual partner of the individual diagnosed of HPV infection, should be examined by a specialist, both physically (external genitalia, anus) and cytologically (vagina, cervix), not only for the detection of CA but also any other associated STD, as well as forewarning cervical or genital cancer in another location.

After treatment of both of them and the disappearance of the visible lesions, they should be informed that the HPV has probably not been eliminated and that the use of condoms may reduce, but not eliminate, the risk of transmission to uninfected partners [19, 20].

\section{Special Situations in Genital Infection by HPV}

\section{Pregnancy}

Due to the existing immunological depression and the higher concentration of steroid hormones during pregnancy there is a higher risk of HPV infection and spread of the disease, to such an extent that we can accept that $2.5 \%$ of all pregnant women have $\mathrm{CA}$, of which a large proportion diminish or regress after delivery, while sub-clinical lesions are hardly modified by pregnancy [21].

The transmission of infection to the newborn is generally produced during its passage through the delivery canal, although there are some studies which detect viral DNA in amniotic liquid with intact membranes. The most important consequence of the viral infection in the newborn is juvenile laryngeal papillomatosis, whose risk is thought to oscillate between 1 in every 400 to 1500 newborns of mothers infected by the virus. They may also develop anogenital CA, especially in newborns born by breech delivery, and very occasionally conjunctive lesions.

Treatment may be carried out with tri- or bichloroacetic acids, cryotherapy, vaporization with $\mathrm{CO}^{2}$ laser or excision with a diathermic knife. The other treatment regimes are contraindicated, except Imiquimod, although this is not recommended by the manufacturer (Table 3) [22].

\section{HPV Infection in Paediatrics}

There are three possible transmission routes:

\section{At the Time of Delivery from an Infected Mother}

Although it is infrequent, this possibility must be considered, above all in children below two years of age. The verruca are found, fundamentally, in the anogenital area in breech births and in the conjunctiva or the larynx in cephalic deliveries (Table 3 ).

2. Autoinoculation in Other Areas or Accidental Heterinoculation

This route is more easily observed in children of over two years old, either from verruca on the child's hands, or verruca from the caretaker's hands. The most prevalent genotype is HPV-2 [23].

\section{Sexual Abuse}

This circumstance is found in $50 \%$ of all anogenital verruca, with the incidence increasing with the age of the child. It is more frequent in girls. The habitual location is the vulva $(40 \%)$, followed by the perianal region $(34 \%)$. The most common genotypes are generally HPV-6, 11, 16 and 18.

The clinical differential diagnosis is simple and the same as for adults. Nonetheless, the problem exists at the time of evaluating the transmission route. In no case should the doctor act in an indolent or passive way, but should understand that it is his moral obligation to try to clarify if a situation of child abuse exists. On the other hand he should tread very carefully since the desire of the doctor to protect the child should not lead to falsely accusing an innocent adult. 
In the first place, it is necessary to rule out verruca in other areas of the child themselves or those who live with the child. If these were not evident, sub-clinical lesions should be sought using the acetic acid test.

In the second place the typification should be carried out of the genotype and subtypes of the verruca of the child and adult in the case that they had them. The information obtained would allow us to know if it were a genotype of typical sexual transmission or not and to know if concordance exists with the genotype of the adult's verruca.

In the third place, the existence of other sexually transmitted diseases should be investigated.

If the findings observed lead to the suspicion of child abuse, and before making the suspicion public, the opinion of other specialists should be sought (it should be a multidisciplinary study among dermatologists, gynaecologists, paediatricians, psychologists). Once consensus is obtained of the suspicion, it should be reported to the judge. It should be remembered that a denouncement to the judge only transmits the suspicion and it is the judge, with the investigations that they consider necessary, who will decide if there has or has not been sexual abuse [24].

\section{REFERENCES}

[1] Bologna JL, Jorizzo JL, Rapini RP. Dermatología $1^{\text {a }}$ edición español. Madrid: Elsevier España, SA 2004.

[2] Mitsuishi T, Wakabayashi T, Kawana S. Topical imiquimod associated to a reduction of heel hyperkeratosis for the treatment of recalcitrant mosaic plantar warts. Eur J Dermatol 2009; 19: 268-9.

[3] Stefani M, Bottino G, Fontenelle E, Azulay DR. Efficacy comparison between cimetidine and zinc sulphate in the treatment of multiple and recalcitrant warts. An Bras Dermatol 2009; 84: 239.

[4] Summers P, Richards-Altmon P, Halder R. Treatment of recalcitrant verruca vulgaris with Candida antigen in patient with human immunodeficiency virus. J Drugs Dermatol 2009; 8: 268-9.

[5] Syrjanen K. Syrjanen S. Infections in human pathology. Chichester: John Wiley-Sons 2000.

[6] Rodríguez Cerdeira MC. Síntesis de controversias en Venerelogia. En: Olmos Acebes L. La consulta de ETS (tomo 2). Trébol y comunicación: Madrid 2005; pp. 62-7.

[7] De Sanjosé S, Bosch FX, Muñoz N, et al. Screening for genital HPV: Results from an international sutdy on HPV sampling techniques. Diagn Mol Pathol 1999; 8: 26-31.

[8] De San Jose S, Valls I, Cañadas MP, et al. La infección por el Virus del Papiloma Humano (VPH) y el virus de la immunodeficiencia (VIH) como factores de riesgo para el cáncer de cuello uterino en mujeres reclusas. Med Clin (Barcelona) 2000; 115: 81-4.

[9] Rodríguez-Cerdeira MC, Alba A, Bravo G, Alcántara R. El virus del papiloma humano y su repercusión en la patología genital femenina. Piel 2007; 22: 1171-80.

[10] Bosch FX, Rohan T, Schneider A, et al. Papillomavirus research: updating results to the year 2000. Highlights of the HPV 2000 International Papillomavirus Conference. J Clin Pathol 2001; 54: 163-75.

[11] Sauder DN, Skinner RB, Fox TL, Owens M. Topical imiquimod $5 \%$ cream as an effective treatment for external genital and perianal warts in different patient populations. Sex Transm Dis 2003; 30: 124-8.

[12] Stockfleth E, Beti H, Orasan R, et al. Topical Polyphenon E in the treatment of external genital and perianal warts: a randomized controlled trial. Br J Dermatol 2008; 158: 1329-38.

[13] Colombo-Benkmann M, Tübergen D, Buchweitz O, Senninger N Ultrasonic technology: a new treatment option for anal condylomata acuminata. Dis Colon Rectum 2008; 51: 1681-5.

[14] Colombo-Benkmann M, Tübergen D, Buchweitz O, Senninger N. Intraurethral fluorouracil and lidocaine for intraurethral condyloma acuminata. Am J Health Syst Pharm 2008; 65: 1830-3.

[15] Gupta S, Malhotra AK, Verma KK, Sharma VK. Intralesional immunotherapy with killed Mycobacterium $\mathrm{w}$ vaccine for the treatment of ano-genital warts: an open label pilot study. Eur Acad Dermatol Venereol 2008; 22: 1089-93.

[16] Rossi R, Bruscino N, Ricceri F, Grazzini M, Dindelli M, Lotti T. Photodynamic treatment for viral infections of the skin. G Ital Dermatol Venereol 2009; 144: 79-83.

[17] Beaulieu D, Burnouf M, Plantier F, et al. Extensive oral condylomas treated by in situ cidofovir injection in an HIV patient. Ann Dermatol Venereol 2008; 135: 307-11.

[18] Brockmeyer NH, Poffhoff A, Bader A, et al. Treatment of condylomata acuminata with pegylated interferon alfa- $2 b$ in HIVinfected patients. Eur J Med Res 2006; 11: 27-32.

[19] Rodríguez-Cerdeira C. Aspectos sociales, éticos y médico-legales de las infecciones transmitidas por vía sexual. Vilata CJJ, Ed. Venereología: aspectos epidemiológicos y clínicos de las infecciones. Madrid: Aula médica 2004.

[20] Maw RD, Reitano M, Roy M. An international survey of patients with genital warts: perceptions regarding treatment and impacto on lifestyle. Int J STD AIDS 1998; 9: 571-8.

[21] Lorincz AT, Reid R. Virus del papiloma humano. Parte I y II. Clin Gin Obst Temas Actuales. México: McGraw-Hill Interamericana 1996; vol. 3 y 4.

[22] De Palo G, Chanen W, Dexeus S. Patología y tratamiento del tracto genital inferior. Masson: Barcelona 2000.

[23] Allen M, Siegried EC. The natural history of condyloma in children. J Am Acad Dermatol 1998; 39: 951-5.

[24] Hammerschlang MR. Sexually transmitted diseases in sexually abused children: medical and legal implications. Sex Transm Infect 1998; 74: 167-74. 